\title{
Peran Pimpinan Pondok Pesantren Dalam Meningkatkan Kualitas Dakwah Santri
}

\author{
M.S. Ghazi Alkhairy ${ }^{{ }^{*}}$ \\ Jurusan Manajemen Dakwah, UIN Sunan Gunung Djati, Bandung \\ *Email : ajialkhoiry@gmail.com
}

\begin{abstract}
The purpose of this research is to know the role (the region of influence), the role of leadership in directing the program, and the role of the leader in supervising the program of activities to improve the quality of preaching santri in Pondok. Pesantren Cipari. The method used in this research is to use descriptive method, through qualitative approach The role of the leadership of Pondok Pesantren Cipari in directing the process of education in order to improve the quality of da'wah santri continues to be developed, it can be seen from the continuous activities of the santri to support the ability in da'wah and it is reflected in one of the activities of boarding school that is mubadharah routinely run every week. The role of the leadership of Pondok Pesantren Cipari in directing the program is seen in the organizing process which resulted in a formulation of organizational structure and delegation of authority and responsibility, a pattern that is built very distinctive, deliberation to consensus other than the leader also performs its function as a policy maker. The usual surveillance process at Pondok Pesantren Cipari by taking the course of the implementation of the activity, measuring its success and failure with the standard as it has been set.
\end{abstract}

Keywords: Role; Leader; Islamic boarding school;

\section{ABSTRAK}

Penelitian ini dilakukan untuk bertujuan mengetahui peran (Wilayah pengaruh), peran pimpinan dalam mengarahkan program, serta peran pimpinan dalam mengawasi program kegiatan untuk meningkatkan kualitas dakwah santri di Pondok Pesantren Cipari.Metode yang digunakan dalam penelitian ini adalah menggunakan metode deskriptif, melalui pendekatan kualitatif. Peran pimpinan Pondok Pesantren Cipari dalam mengarahkan proses pendidikan guna meningkatkan kualitas dakwah santri terus dikembangkan, hal tersebut terlihat dari terus berjalannya kegiatan-kegiatan para santri untuk menunjang kemampuan dalam berdakwah dan hal tersebut tercermin dalam salah-satu kegiatan pondok pesantren yaitu muhadharah yang rutin dijalankan setiap minggunya. Peran pimpinan Pondok Pesantren Cipari dalam mengarahkan program terlihat pada 
proses pengorganisasian yang menghasilkan sebuah rumusan struktur organisasi dan pendelegasian wewenang dan tanggung jawab, pola yang dibangun sangat khas, musyawarah untuk mufakat selain pemimpin pun menjalankan fungsinya sebagai penentu kebijakan. Proses pengawasan yang biasa dilakukan di Pondok Pesantren Cipari dengan mengambil jalannya pelaksanaan kegiatan, mengukur keberhasilan dan kegagalannya dengan standar sebagaimana yang telah di tetapkan.

Kata Kunci : Peran; Pimpinan; Pondok Pesantren;

\section{PENDAHULUAN}

Pesantren merupakan media dan lembaga dakwah Islam di Indonesia didirikan karena adanya tuntutan dan kebutuhan zaman. Sistem pendidikan Islam Indonesia di dirikan yang dikembangkan dapat dilihat dari dua orientasi. Pertama, berorientasi terhadap penguatan basis keagamaan bagi masyarakat muslim. Kedua. sebagai media konsultasi dan sosialisasi terhadap masyarakat nusantara yang belum sepenuhnya menganut agama Islam. Dari pendapai tersebut dikatakan bahwa pesantren selain sebagai media dakwah juga sebagai senjata media umat muslim dalam melakukan strategi dan taktik dakwah dalam melakukan Islamisasi di Nusantara terutama lingkungannya. Menurut Hasbullah, bahwa Pondok Pesantren bisa dijadikan sebagai media dalam berbagai aspek sosial, politik. ekonomi dan budaya. Hal ini menunjukan sejak awal berdirinya difungsikan dalam berbagai aspek sebingga tercipta masyarakat dari sekelompok umat muslim (Hasbullah, 1995: 5)

Kepemimpinan pondok pesantren dalam pengelolaannya berjuang pada dua fungsi pelayanan: fungsi kemasyarakatan, yang bermuara keopada pelayanan dalam bentuk pelayanan agama pada masyarakat dan pengelola teknis pada pesantren. yang bennuara pada pelayanan pengawasan administratif yang baik, pembinaan calon pengganti yang teratur, pengelolaan sistem pendidikan secara organisatoris (Wahid, 2001: 143). Dalam pondok pesantren, kepemimpinan kyai sangat berperan dalam pengelolaan pondok pesantren tersebut. Relasi sosial yang di bangun antara kyai-ulama-santri di landasi kepercayaan, bukan karena adanya tingkat jabatan seperti kepemimpinan konvensional, tetapi dalara kepemimpinan pondok pesantren ketaatan santri kepada kiyai akan dapat mendatangkan barokah.

Untuk meningkatkan pengelolaan terhadap pesantren tentu tidak lepas dan pengaruh pola kepemimpinan yang di terapkan oleh pimpinan. Kepemimpinan merupakan suatu proses yang mengandung unsur mempengaruhi, adanya kerja sama dan mengarah pada suatu hal dan tujuan bersama dalam sebuah organisasi. Kepemimpinan mempunyai peran sentral dalam dinamika kehidupan organisasi. Kepemimpinan berperan sebagai penggerak segala sumber daya manusia dan 
sumber daya lain yang ada dalam organisasi (Arifin 2004:23).

Kepala pondok dalam memimpin lembaga di pesantren menunjukan bahwa kepala pondok adalah seorang yang rnenentukan titik pusat dan irama suatu pondok pesantren, selaku top leader mempunyai wewenang dan kekuasaan serta gaya kepemimpinan untuk mengatur dan mengembangkan bawahannya secara profesional. Bahkan dapat dikatakan bahwa keberhasilan pondok pesantren adalah keberhasilan kepala pondok. Dalam hal ini kepaia pondok merupakan salah satu komponen yang paling berperan dalam meningkatkan kegiatan dakwah di lingkungannya.

Kepemimpinan dalam Islam adalah suatu dasar suatu konsep pemimpin dan kepemimpinan sebagai salah satu tugas penting dalam Islam mensyaratkan terlebih dahulu memahami kedudukan manusia menurut Al-qur'an dalam kontek Alqur'an manusia selain harus menyembah dan beribadah kepada Allah juga berfungsi sebagai khalifah Allah di muka bumi. Dari fungsi sebagai kholifah inilah kemudian banyak mendasari konsep kepemimpinan (imamah) dalam Islam.

Max Weber misalnya meninjau masalah kepemimpinan dan sudut pandang legalitas otorita. Weber membedakan legalitas otorita menjadi tiga, yaitu otorita rasional, otorita tradisional dan otorita kharismatik Otorita rasional mernpunyai hubungan formal dan birokratis tipe monokratik merupakan salah satu bentuk kepemimpinan rasional berdasarkan kopetensi teknik otorita tradisional mempertahankan legalitas otorita dan menuntut orang lain agar mengakui otorita tersebut dengan berlindung dibalik baju tradisi. Otoritas patrimonial merupakan otorita tradisional yang didesentralisasikan. Otorita patrimonial memperoleh otorita benkut imbalan-imbalan kemudahan, seperti pinjaman tanah garapan, pembebasan pajak, legalitas otorita karismatik di peroleh oleh seorang karena karismanya pribadinya, bukan karena kemudahan sosial ataupun kompetensi teknik (Weber, 1999: 2-3).

Optimalisasi fungsi manajemen dalam meningkatkan peran dan fungsi masjid. Hasilnya mengungkapkan bahwa "Terlaksananya pengorganisasian yang efisien memiliki arti yang sangat penting, sebab dalam pelaksanaannya akan mempermudah penugasan kepada staf pengurus, karena sudah jelas seksi apa dan siapa yang harus melaksanakan suatu bidang tegiatan, memudahkan dipilihnya tenaga pelaksana yang tepat, karena dalam pengorganisasian bukan hanya menyusun struktur dan menempatkan orangnya, tetapi juga menguraikan tugas dan tanggung jawabnya sehingga bisa dipilih siapa yang tepat unuk menempati posisi suatu kepengurusan. Pengorganisasian juga akan membuat terpadunya berbagai potensi pengurus dan suatu kerangka kerjasama pemakmuran masjid serta dengan pengorganisasian juga akan memudahkan bagi pemimpin untuk mengendalikan dan mengevaluasi pelaksanaan suatu kegiatan."

Fokus dari penelitian ini adalah peranan pemimpin dalam meningkatkan kualitas dakwah santri dan hasil dari program kegiatan. Berdasarkan latar belakang 
diatas, maka focus penelitiannya adalah 1) Bagaimana peran (wilayah pengaruh) pimpinan untuk meningkatkan kualitas dakwah santri di Pondok Pesanrren Cipari, 2) Bagaimana peran pimpinan dalam mengarahkan program untuk meningkatkan kualitas dakwah santri di Pondok Pesantren Cipari. 3) Bagaimana peran pimpinan dalam mengawasi program kegiatan untuk meningkatkan kualitas dakwah santri di Pondok Pesantren Cipari.

Lokasi Penelitian berada di Jl. Cipari Desa Sukarasa Kecamatan PangatikanKabupaten Garut lokasi ini dipilih karena Pondok PesantrenCipari ini kiyai sangat berperan dalam meningkatkan kualitas Pendidikan dakwah Santri di pondok Pesantren serta berpengaruh bagi Masyarakat.

Metode penelitian yang digimakan adalah metode deskriptif, yaitu metode yang digunakan untuk menggambarkan atau menjelaskan peran kepemimpinan kyai dan ustadznya dalam meningkatkan kualitas santri dan pondok pesantren. Metode penelitian yang berusaha mendeskripsikan gejala, peristiwa. kejadian yang terjadi pada saat sekarang (Sudjana, 1989: 68) alasan digunakannya metode ini karena penelitian ini bersifat aktual dan bertujuan untuk menggambarkan keadaan atau status fenomena.

\section{HASIL DAN PEMBAHASAN}

Kepemimpinan adalah kemampuan dari seorang untuk mempengaruhi oranglain, sehingga oranglain tersebut bertingkah laku sebagaimana yanng dihendaki oleh pimpinan tersebut. Kadang kala kepemimpinan di bedakan sebagai kedudukan dan kepemimpinan sebagai suatu proses sosial, sebagai kedudukan, kepemimpinan merupakan suatu kompleksdari hak-hak dan kewajiban yang dapat dimiliki oleh seseorang seagai suatu proses sosial kepemimpinan meliputi segala tindakan yang dilakukan seorang atau suatu badan, yang menyebabkan gerak dari warga masyarakat (Abu Ahmadi, 1999:132).

Kepemimpinan dan manajemen seringkali disamakan pengertiannya oleh banyak orang. Walaupun demikian antara keduanya terdapat perbedaan yang penting untuk diketahui. Pada hakikatnya kepemimpinan mempunyai pengertian agak luas dibandingkan manajemen. Manajemen merupakan jenis pemikiran yang khusus dari kepemimpinan didalam usahanya mencapai tujuan organisasi. Kunci perbedaan diantara kedua konsep pemikiran terjadi setiap saat dan dimana pun asalkan ada seseorang yang berusaha untuk mempengaruhi prilaku orang lain atau kelompok, tanpa mengindahkan bentuk alasannya.

Dengan demikian kepemimpinan bisa saja karena berusaha mencapai tujuan seseorang atau tujuan kelompok, dan itu bisa saja sama atau tidak selaras dengan tujuan organisasi. Dengan kata lain seorang leader atau pemimpin belum tentu seorang manajer, tetapi seorang manajer bisa berprilaku sebagai seorang pemimpin (Permadi, 2010:11-13).

Kepemimpinan sesungguhnya tidak ditentukan oleh pangkat atau pun 
Peran Pimpinan Pondok Pesantren dalam Meningkatkan Kualitas Dakwah Santri jabatan seseorang. Kepemimpinan adalah suatu yang muncul dari dalam dan merupakan buah dari keputusan seseorang untuk mau menjadi pemimpin, baik bagi dirinya sendiri, bagi keluarganya, bagi lingkungannya, pekerjaannya, maupun bagi lingkungan sosial dan bahkan bagi negrinya. Kepemimpinan adalah sebuah keputusan dan lebih merupakan hasil dari proses perubahan atau transformasi internal dalam diri seseorang.

Kepemimpinan bukanlah jabatan atau gelar, melainkan sebuah kelahiran dari proses panjang perubahan dalam diri seseorang, ketiaka seseorang menemukan visi dan misi hidupnya, ketika terjadi kedamain dalam diri dan membentuk bangunan karakter yang kokoh, ketika setiap ucapan dan tindakannya mulai memberikan pengaruh kepada lingkunganntya, dan ketika keberadaan mendorong perubahan dalam organisasinya, pada saat itulah sesorang lahir menjadi pemimpin sejati.

Pemimpin adalah seseorang yang mempunyai bawahan untuk mengerjakan sebagai pekerjaan sebagai pekerjaannya dalam mencapai tujuan. Pemimpin di bedakan atas: Top manager (pemimpin puncak) midle manager (manajer madya) dan lowermanager (manajer bawah) pemimpin juga dibedakan menjadi dua bagian leader dan head.Pertama, leader adalah pemimpin yang mempunyai sifatsifatkepemimpinan yang baik, praktik kepemimpinan juga persuasive, (bujukan), komunikasinya dua arah (two way ttraffic), gaya kepemimpinan persuasif, mempunyai authority, power dan personality serta di senangi disegani, dan di hormati oleh pengikutnya, falsafah kepemimpinannya, pemimpin adalah untuk bawahan, kedua head adalah pemimpin yang kepemimpinannya didasarkan kepeda kekuasaan (power), peraktik kepemimpinannya intruksi (perintah), komunikasinya satu arah (one way ttraffic) gaya kepemimpinannya autocrat (otoriter) serta kurang disenangi dan kurang dekat oleh bawahan. Falsafah kepemimpinannya, bawahan untuk pemimpin (H. Maluyu, 1996:204).

Teori genetis ini menyatakan bahwa "Leader are born and not made (pemimpin itu dilahirkan dari bakat, bukannya dibuat). Para penganut aliran teori ini mengetengahkan pendapatnya bahwa seorang pemimpin akan menjadi pemimpin karena ia telah diiahirkan dengan bakat. Dalam keadaan yang bagaimanapun seseorang ditempatkan karena ia telah ditakdirkan menjadi pemimpin, sesekali kelak ia akan timbul sebagai pemimpin.

Teori Sosial, teori ini mempunyai pandangan bahwa "leader are made and not bom" (pemimpin itu dibuat atau dididik bukannya kodrati). Teori ini merupakan kebalikan dari teori genetika. Para penganut teori ini mengetengahkan pendapat yang mengatakan bahwa setiap orang bisa menjadi pemimpin apabila diberikan pendidikan dan pengalaman yang cukup. menurut teori ini pada hakekatnya semua orang sama dan dapat menjadi pemimpin.

Teori Ekologis yaitu teori yang pada intinya seseorang hanya akan berhasil menjadi pemimpin yang baik apabila ia telah memiliki bakat kepemimpinan. Bakat 
tersebut kemudian dikembangkan melalui dikembangkan lebih Ianjut. Teori ini menggabungkan segi-segi positif dari kedua teori terdahulu (Athoillah, 2010: 149).

Dakwah merupakan Seruan atau ajakan kepada keinsafan, atau usaha mengubah situasi yang tidak baik kepada situasi yang lebih baik dan sempurna baik terhadap pribadi maupun masyarakat. (Shihab, 1992: 194).

Secara substasial, pesantren merupakan institusi keagamaan yang tidak mungkin bisa dilepaskan dari masyarakat, khususnya masyarakat pedesaan. Lembaga ini tumbuh dan berkembang dari dan untuk masyarakat dengan memposisikan dirinya sebagai bagian masyarakat dalam pengertiannya yang transformatif. Dalam konteks ini, pendidikan pesantren pada dasarnya merupakan pendidikan yang sarat dengan nuansa transformasi sosial. Pesantren berikhtiar meletakan visi dan kiprahnya dalam kerangka pengabdian sosial yang pada mulanya ditekankan kepada pembentukan moral keagamaan dan kemudian dikembangkan kepada rintisan-rintisan pengembangan yang lebih sitematis dan terpadu (A'la, 2006:2-3).

Pada dasarnya, tujuan didirikannya pondok pesantren di bagi manjadi dua, yaitu; tujuan umum, membimbing para santri untuk menjadi manusia yang kepribadian Islam yang sanggup dengan ilmu agamanya menjadi mubaligh di tengah masyarakat. Tujuan khusus, mempersiapkan para santri untuk menjadi orang ahli agama, serta mengamalkannya dalam kehidupan bermasyarakat (Noor, 2006:20).

Secara etimologis, dakwah berasal dari bahasa Arab, yaitu da'a yad'u da'wan du'a yang diartikan sebagai mengajak menyeru, memanggil, seruan, permohonan, dan permintaan. Istilah ini sering di beri arti yang sama dengan istilah-istilah Tabligh, amr ma'ruf dan nahi munkar, mau' idzhoh hasanah, tabsyir, indzar, washiyah, tarbiyah, ta,lim dan khotbah.(Majma al-lughah al-rabiyah, 1972: 286).

Unsur-unsur Dakwah terdiri dari : 1) Da’i (pelaku dakwah), Nasarudin lathief mendefinisikan bawa da’i adalah muslim muslimat yang menjadikan dakwah sebagai suatu amaliah pokok bagi tugas ulama. Ahli dakwah adalah wa'aahd mubaligh mustama'in (juru penerang) yang mengajak, menyeru memberi pengajaran, dan pelajaran agama islam. Da'i juga harus mengetahui cara penyampaian dakwah tentang Allah, alam semesta, dan kehidupan, serta apa yang dihadirkan dakawah untuk memberikan solusi terhadap problema yang dihadapi manusia, juga metodemetode yang dilahirkannya juga untuk menjadikan agar pemikiran dan prilaku manusia tidak salah dan tidak melenceng (Mustafa malaikah 1997:18). 2) Mad'u (penerima Dakwah)Muhamad Abduh membagi mad'u menjadi tiga golongan yaitu:Golongan cerdik dan cendikiawan yang cinta kebenaran dapat berpikir secara kritis, dan cepat dapat menangkap persoalan. Golonga awam, yaitu orang kebayakan yang belum dapat berpikir secara kritis, dan mendalam, serta belum dapat menangkap penegertian-pengertian yang tinggi. Golongan yang berbeda dengan kedua golongan tersebut, mereka senag membahas sesuatu tetapi hanya 
Peran Pimpinan Pondok Pesantren dalam Meningkatkan Kualitas Dakwah Santri dalam batas tertentu saja, dan mampu membahasnya secara mendalam. c) Maddah (materi dakwah), Maddah dakwah adalah isi pesan atau materi yang di sampaikan da'i kepada mad'u. Dalam hal ini sudah jelas bahwa yang menjadi maddah adalah ajaran isalam itu sendiri.

Secara umum materi dakwah dapat diklasifikasikan menjadi empat masalah pokok, yaitu: 1) Masalah akidah (keimanan), 2) Masalah syariah. 3) Masalah muamalah, 4) Masalah akhlak . 5) Wasilah (media) Dakwah, 6) Wasilab (media) dakwah adalah alat yang digunakan untuk menyampaikan materi dakwah (ajaran Islam) kepada mad'u. Untuk menyampaikan ajaran Islam kepada umat, dakwah dapat menggunakan berbagai wasilah. Hamazah yaqub membagi wasilah dakwah menjadi lima macam, yaitu: lisan, tulisan, lukisan, audiovisual,dan akhlak. 7) Thariqah (Metode) Dakwah. Dalam ayat ini metode dakawah ada tiga yaitu :bil alhikmah: mau, izatul hasanah: dan mujadalah billati biya ahsan secara garis besar ada tiga pokok metode (thoriqah) dakwah, yaituAstsar (efek) Dakwah, dalam setiap efektivitas dakwah pasti akan menimbulkan reaksi. Artinya jika dakwah telah dilakukan oleh seseorang da'i dengan materi dakwah, wasilah, dan thoriqoh tentu, maka akan timbul respons dan efek (atsar) pada mad'u (penerima dakwah)

Menurut Jalaludi Rahmat (1982:269) bahwa efek kognitif terjadi bila ada perubahan pada apa yang diketahui, dipahami, atau dipersepsi khalayak. Efek ini berkaitan dengan transmisi pengetahuan, keterampilan kepercayaan, atau informasi. Efek afektif timbul bila ada perubahan pada apa yang dirasakan, disenangi atau di benci khalayak yang meliputi, segala yang berhubungan dengan emosi, serta nilai. Sedangkan efek bihavioral merujuk kepada prilaku nyata yang dapat diamati, yang meliputi pola-pola tindakan, kegiatan atau kebiasaan prilaku. Pesantren Cipari pada hakekatnya merupakan kelanjutan dari pesantren Cidewa dan Cilame yang berdiri sejak tahun 1873 di bawah asuhan Abkaim, KH. Syamsudin,KH Abdullah, dan KH. Hasan. Pada tahun 1984 kegiatan kedua pesantren tersebut mengalami kevakuman karena kondisinya tidak memungkinkan lagi untuk melanjutkan kegiatannya antara lain karena sebagian pendirinya seperti Rewi meninggal dunia dan sebagian lagi seperti Sidik bermukim di tanah suci entahlah menjalankan ibadah haji.

Pada tahun 1895 atas prakarsa putra KH. Syamsudin yaitu KH. Harmaen, dengan dibantu oleh saudara-saudaranya yaitu KH. Ahmad Kisya dan KH. Ahmad Zaeni, dibuka kembali pesantren baru yang mengambil lokasi kampung Cipari, kira-kira $200 \mathrm{M}$ sebelah barat daya pesantren Cilame. Sesuai dengan nama daerah tersebut, maka pesantren ini pun bernama pesantren Cipari.

\section{Peran (Wilayah Pengaruh) Pimpinan dalam Meningkatkan Kualitas Dakwah Santri di Pondok Pesanrren Cipari}

Pengorganisasian dalam pandangan Islam bukan semata-mata merupakan wadah, akan tetapi lebih menekankan bagaimana pekerjaan dapat dilakukan secara rapi, teratur dan sitematis. 
Pada proses pengorganisasian akan menghasilkan sebuah rumusan struktur organisasi dan pendelegasian wewenang dan tanggung jawab. Jadi, yang ditonjolkan adalah wewenang yang mengikuti tanggung jawab, bukan tanggung jawab yang mengikuti wewenang. Islam sendiri sangat perhatian dalam memandang tanggung jawab dan wewenang sebagaimana yang telah dicontohkan oleh Rasulullah SAW. yang mengajak para sahabat untuk berpartisipasi melalui pendekatan empati yang sangat persuasive melalui musyawarah, maka dari itu harus ada beberapa usaha yang harus dilakukan.

Pertama, Usaha Pengembangan Pondok Pesantren, Pondok Pesantren merupakan lembaga keagamaan yang sarat nilai dan tradisi luhur yang telah menjadi karakteristik pesantren pada hampir seluruh perjalanan sejarahnya. Secara potensial, karakteristik tersebut memiliki peluang cukup besar utuk dijadikan dasar kebijakan dalam rangka menyikapi globalisasi dan persoalan-persoalan lain yang menghadang pesantren, secara khusus, dan masyarakat luas, secara umum. Misalnya, kemandirian, keikhlasan, dan kesederhanaa, ketiganya merupakan nilainilai yang dapat melepaskan masyarakat dari dampak negative globalisasi dalam bentuk ketergantungan dan pola hidup konsumerisme yang lambat tapi pasti akan menghancurkan sendi-sendi kehidupan manusia (A'la, 2006:9). Pada hasil wawancara dengan Ustadz Sholeh pada tanggal 09 Febuari 2018 pada pukul 13:45 WIB , beliau mengatakan bahwa :

"Pondok Pesantren Cipari terus berkembang dari tahun ke tahun, hal tersebut terlihat dari semakin berkembangnya infrastruktur pondok pesantren dan terus bertambahnya fasilitas pondok pesantren. Hal tersebut tidak bisa dilepaskan dari upaya-upaya pimpinan pondok pesantren dalam menjalankan "roda ekonomi" pondok pesantren. Berdasarkan hasil wawancara penulis, Pondok pesantren Cipari mendapatkan dana untuk pembangunan dan perbaikan fasilitas dari hasil iuran santri, alumni, pemerintah desa setempat, dan para donator. Pimpinan pondok pesantren pun turut serta dalam pengembangan potensi ekonomi masyarakat setempat dalam bidang peternakan, pertanian, koperasi dan waserda".

Kedua, Usaha dalam pendidikan dan dakwah, selanjutnya salah satu aktivitas keagamaan yang secara langsung digunakan untuk mensosialisasikan ajaran Islam bagi penganutnya dan umat manusia pada umumnya adalah aktivitas dakwah. Aktivitas ini dilakukan baik melalui lisan, tulisan, maupun perbuatan nyata. Secara kualitatif dakwah Islam bertujuan untuk mempengaruhi dan mentransformasikan sikap batin dan perilaku warga masyarakat menuju suatu tatanan keshalehan individu dan keshalehan sosial. Dakwah dengan pesan-pesan keagamaan dan pesan-pesan sosialnya juga merupakan ajakan kepada kesadaran untuk senantiasa memiliki komitmen (istiqamah) di jalan yang lurus. Dakwah adalah ajakan yang dilakukan untuk membebaskan individu dan masyarakat dari pengaruh eksternal nilai-nilai syaithaniah dan kejahiliahan menuju internalisasi nilai-nilai ketuhanan 
(Munir, 2006: 1-2).

Pondok Pesantren Cipari menerapkan beberapa metode dalam menerapkan pendidikan dakwah santri; 1) Muhadharah, Muhadharahadalah kegiatan yang rutin dilakukan dan dipertanggungjawabkan olehsantri yang menjadi pengurus di Pondok Pesantren Cipari. Kegiatan mubadharah merupakan salah satu sunnah dan disiplin pondok yang harus diikuti oleh seluruh santri. Selain itu, mubadharah juga merupakan salah satu kegiatan ekstrakulikuler yang wajib diikuti oleh seluruh santri. Dengan demikian santri yang tidak mengikuti kegiatan mubadharah akan mendapatkan sanksi.Sebuah organisasi sudah tentu harus memiliki banyak factor pendukung agar tetapberjalannya organisasi tersebut, begitu pun dalam kegiatanmuhadharah, terdapat beberapa unsur penting yang mendukung berjalannya pelaksanaan kegiatan tersebut. Unsur inilah yang menjadi faktor pendukung berjalanya kegiatan mubadharah selama ini. Unsur-unsur yang ada dalam pelaksanaan kegiatan muhadharah di Pondok Pesantren Cipari yaitu; Dalam suatu kegiatan tidak terlepas dari orang-orang yang terlibat didalamnya. Peserta merupakan bagian dari sistem kaderisasi yang terlibat aktif, karena merekalah yang menjadi target kaderisasi untuk dilatih dan dibina manjadi kader-kader yang berkualitas di masa yang akan datang. Kegiatan mubadharah yang diterapkan di Pondok Pesantren al-mubayyidliyah menempatkan peserta sebagai salah satu unsur yang terlibat dalam model kaderisasi, karena merupakan sasaran utama yang dipersiapkan sebagai calon-calon mubaligh. Sedangkan yang menjadi peserta dalam kegiatan muhadharah ialah para santri Pondok Pesantren Cipari secara umum. 2) Bentuk pelaksanaan kegiatan dakwah Santri, pada setiap kegiatan terdapat mekanisme-mekanisme yang harus dilakukan. Begitu juga kegiatan muhadharah, memiliki beberapa mekanisme pelaksanaan. Mekanisme ini sebagai panduan dalam pelaksanaan kegiatan muhadharah. adapun mekanisme dalam kegiatan mubadharah adalah: Perencanaanmembentukkelompok muhadharah, menentukan pembimbing dan pengawas setiap kelompok mubadharah. hal ini dilakukan agar kegiatan muhadharah berjalan begitu tertib. Adapun untuk jumlah kelompok muhadharah santri dibagi beberapa kelompok. Setiap kelompok membuat jadwal piket untuk acara mubadharah. seperti membuat jadwal piket ruangan, penceramah, MC, pembaca ayat suci Al-Qur' dan lain sebagainya.

Hal lain yang dipersiapkan oleh pengurus atau bagian pendidikan adalah menentukan tema mubadharah. agar tema yang dibuat seragam dan tidak ada kecurangan dalam membuat isi pesan ceramah. Maka dari itu tema bagian terpenting dalam peristiwa public speaking. Sedangkan bagi santri yang memiliki jadwal ceramah, dalam tahap persiapan ini memiliki kewajiban membuat bahan ceramah. (Wawancara dengan Muhammad Sholih selaku penanggung jawab acara muhadharah). Pada tahap pelaksanaan, pengurus menentukan waktu kegiatan muhadharah, tempat dilaksanakannya bagi setiap kelompok, dan susunan acara kegiatan muhadharah berlangsung. Waktu mubadharah santri Pondok Pesantren 
Cipari adalah setiap malam Sabtu dan Minggu pukul 20:00-22:00. Durasi pada santri yang pidato yaitu: sekitar 10-15 menit, adapun tempat pelaksanaan mubadharah yaitu di aula Pondok Pesantren Cipari atau yang biasa disebut madrasah.

Pengawasan dan evaluasi untuk menghasilkan sesuatu yang diharapkan dalam sebuah kegiatan, maka diperlukan adanya evaluasi dan pengawasan sebagai bagian dari mekanisme kegiatan kegiatan tersebut. Pengawasan yang dimaksud dalam kegiatan muhadharah adalah perhatian dan pengontrolan berlangsungnya kegiatan tersebut sehingga jika terjadi kesalahan dalam pelaksanaannya segera di lakukan perbaikan dan peringatan yang sesuai dengan rencana yang diharapakan. Dalam kegiatan mubadharah ini pengawasan dan evaluasi dilakukan oleh bagian pendidikan santri sebagai penanggung jawab dari kegiatan mubadharah. Dari hasil wawancara dengan Ustadz Misbah yang bertugas mengevaluasi seluruh kegitan Muhadhara, maka beliau memaparkan bahwa :

"Pengawasan yang dilakukan dalam kegiatan ini melalui pembimbing dari masing-masing kelompok selama berlangsung peroses kegiatan tersebut. Bentuk pengawasan yang dilakukan oleh bagian pendidikan santri terhadap pelaksanaan kegiatan muhadharah diantaranya: melihat secara langsung jalanya kegiatan muhadharah, memberikan teguran, peringatan dan sangsi, memberikan pengarahan kepada masing-masing ketua kelompok muhadharah., menggerakkan dan memeriksa santri di asrama-asrama untuk mengikuti kegiatan ini. Selain diadakan pengawasan dalam kegiatan muhadharah juga diadakan evaluasi, maksudnya untuk mengadakan perbaikan dan penyempurnaan juga untuk menumbuhkan kompetisi yang sehat bagi masing-masing kelompok. Evaluasi dalam kegiatan ini dilakukan oleh pembimbing kelompok masing-masing dan bagian pendidikan santri. Bentuk evaluasi yang dilakukan oleh pembimbing pada kelompok yang dibimbingnya adalah memberikan penilaian kepada pera peserta yang tampil, mendiskusikan pada masing-masing kelompok untuk kegiatan berikutnya. Sedangkan evaluasi pada kegiatan muhadharah pada seluruh kelompok yang dilakukan oleh bagian pendidikan adalah memberikan penilaian pada kelompok terbaik dan mengumumkannya pada akhir semester, mengadakan diskusi setiap bulan dengan kelompok muhadharah."

Muhadharah adalah aktivitas kegiatan dalam upaya melatih mental dan pengembangan potensi (bakat) yang terpendam untuk mendapatkan suatu keahlian yang ada pada diri sendiri dan mesti dimiliki. Muhadharah ini, dapat dilakukan dengan cara menjadi pembawa acara, memberi sambutan, baca Qur'an, shalawat, penceramah dan keterampilan Islam serta do'a yang ditampilkan di depan umum atau di depan santri. Proses evaluasi: 1) Kemampuan santri sebelum dibina dan setelah dibina, 2) Langkah-langkah yang harus dilaksanakan untuk 
Peran Pimpinan Pondok Pesantren dalam Meningkatkan Kualitas Dakwah Santri merumuskan dakwah santri itu apa.3) Program-program yang kongkrit apa saja yang sudah dilaksanakan untuk merumuskan dakwah santri.Dakwah adalah ajakan yang dilakukan untuk membebaskan individu dan masyarakat dari pengaruh eksternal nilai-nilai syaithaniah dan kejahiliahan menuju internalisasi nilai-nilai ketuhanan (Munir, 2006: 1-2).

\section{Peran Pimpinan dalam Mengarahkan Program untuk Meningkatkan Kualitas Dakwah Santri di Pondok Pesantren Cipari}

Actuating atau disebut juga gerakan aksi mencakup kegiatan yang dilakukan oleh seorang manajer untuk mengawali dan melanjutkan kegiatan yang ditetapkan oleh unsur perencanaan dan pengorganisasian agar tujuan-tujuan dapat tercapai. Sedangkan controlling merupakan kelanjutan tugas untuk melihat apakah kegiatan-kegiatan dilaksanakan sesuai dengan rencana (Kusnawan, 2015).Pondok Pesantren Cipari pun memiliki beberapa program kegiatan yang rutin dilakukan dan dijalankan sesuai dengan jadwalnya seperti kegiatan PHBI, pendidikan formal setiap hari, pengajian rutin, pengajian khusus, ekstrakulikuler, dll. Programprogram tersebut terus dijalankan setiap harinya dan dievaluasi setiap waktu.

"Pesantren sebagai lembaga pendidikan keagamaan merupakan realitas yang tak dapat dipungkiri. Sepanjang sejarahnya, pesantren terus menekuni pendidikan tersebut dan menjadikannya sebagai fokus kegiatan. Dalam mengembangkan pendidikan, pesantren telah menunjukan daya tahan yang cukup kokoh sehingga mampu melewati berbagai zaman dengan beragam masalah yang dihadapinya. Dalam sejarahnya itu pula, pesantren telah menyumbangkan sesuatu yang tidak kecil bagi Islam di negeri ini." (A'la, 2006: 15).

Pimpinan Pondok Pesantren Cipari membangun proses pembelajaran dengan santri melalui kurikulum dan sebuah metode yang khas.Pertama, Metode yang di terapkan oleh pimpinan. Sesuai dengan hasil wawancara dengan pimpinan pondok pesantren menyatakan bahwa

"Ada beberapa metode yang diterapkan kepada para santri oleh Pimpinan Pondok Pesantren Cipari dalam meningkatkan kemampuan dakwah santri. Metode tersebut diantaranya: metode balagan, metode sorogan, metode muhadoroh."

Metode Balaghan yaitu metode transfer ilmu dari para ustadz kepada santrinya. Dengan cara ustadz membacakan kitab secara perlahan berikut terjemahannya. Kemudian para santri mencatat artinya dibawah baris huruf didalam kitab yang dikaji. Hal ini dilakukan secara terus menerus setiap hari dengan jadwal dan kitab yang telah ditentukan.

Metode Sorogan yaitu metode transfer ilmu dari para ustadz kepada santrinya. Dengan cara ustadz membacakan kitab kuning secara perlahan, kemudian para 
santri mengulang bacaannya sesuai dengan apa yang diucapkan oleh sang ustadz. Pengulangan santri terus diulang hingga santri tersebut dapat mengingat artinya ketika suatu saat ingin membaca kembali kitab tersebut.

Dua metode tersebut digunakan oleh pimpinan pondok untuk mentransferkan ilmu pesantren kepada para santrinya guna sebagai bekal materi yang akan di dakwahkan oleh para santri. Setelah ilmu sang guru di transferkan maka pimpinan pondok menerapkan program muhadoroh kepada para santrinya. Metode mudhaaroh yaitu metode latihan dakwah santri. Dengan cara mengadakan suatu acara pengajian yang penceramahnya dari para santri sendiri. Metode ini diterapkan oleh pimpinan kepada para santrinya sebagai wahana penerapan materi yang telah di berikan oleh para guru. Metode ini juga digunakan sebagai ajang latihan dakwah para santri. Agar terbiasa dalam berdakwah serta sebagai peningkatan soft skill dakwah para santri di Pesantren Cipari.

Selain daripada metode yang telah disebutkan diatas, para santri mencari sendiri metode bedakwah yang akan digunakan pada referensi-referensi yang lain misal buku dan internet. Kemudian Pimpinan pondok juga menerapkan metode dakwah di dunia maya atau di internet. Karena selain daripada imtak pimpinan pondok juga menerapkan pengajaran iptek kepada para santrinya agar tidak tertinggal oleh zaman yang serba modern. Maka dari itu pesantren tidak hanya melaksanakan pendidikan secara tradisional tetapi juga menerapkan pendidikan secara medern dalam arti tradisional-modern.

"Ketika menjadi seorang pembimbing, seseorang paling tidak perlu memiliki beberapa keterampilan yang menunjang seseorang menjadi kompeten dalam membimbing. Mulai dari Keterampilan membentuk-pesan menambah keakuratan dan kejelasan pesan yang dikirim. Kemudian Keterampilan suasana-percakapan menambah kemungkinan seseorang dan partnernya mengembangkan hubungan yang saling mendukung, yaitu hubungan yang menimbulkan kepercayaan satu sama lain. Selanjutnya, keterampilan mendengarkan untuk memahami menambah kemungkinan seseorang bisa memahami makna orang lain. Tak kalah penting, keterampilan empati-respon menambah kemungkinan seseorang mampu memahami dan merespon pengalaman emosional orang lain. Serta, Keterampilan menyingkap menambah kemungkinan seseorang akan berbagi gagasan dan perasaan dengan cara yang jujur dan sensitif. Persiapan yang mantap sebelum pelaksanaan latihan akan membantu dan menjamin lancarnya pelaksanaan latihan, serta tercapainya sesuai dengan yang diharapkan.

Walaupun demikian, selama proses latihan masih sering muncul perkembangan dan masalah yang tidak terbayangkan sebelumnya. Masalah itu adakalanya berkaitan dengan materi, judul, pelatih, ataupun peserta. Oleh karenanya selama pelaksanaan pelatihan diperlukan kesiapan dan kesediaaan pihak 
Peran Pimpinan Pondok Pesantren dalam Meningkatkan Kualitas Dakwah Santri penyelenggara untuk mengadakan penyesuaian bila memang perlu. Agar dapat diadakan penyesuaian yang tepat dan dilakukan pada waktu yang tepat juga. Untuk itu hendaknya ada upaya penyesuaian yang dapat dilakukan.

Paling tidak ada empat fungsi dasar fungsi fasilitatif dari seorang fasilitator, yaitu: Pertama, Stimuli emosional, menggambarkan prilaku fasilitator yang bergairah, ekspresif yang berpribadi dan penuh emosi. Fungsi ini dilaksanakan di tengah para peserta. Kedua, Kepedulian, adalah isu yang terpisah dari keahlian teknis. ia dibuktikan dengan pengembangan khusus, yang hangat dengan anggota kelompok. Ketiga, Atribut yang bermanfaat. Ia dicapai dengan pesiapan penjelasan perilaku perubahan kognitif dan definisi kerangka kerja untuk berubah. Hal ini memberikan manfaat untuk pengalaman. Keempat, Fungsi ekskutif, yaitu pendekatan."

Kedua, Program yang dikembangkan pimpinan pondok pesantren dalam meningkatkan dakwah santri.a) Menyalurkan bakat dan meningkatkan kreativitas santri dengan melengkapi segala sarana dan prasaran yang dibutuhkan atau kajiankajian.b)Kaderisasi santri, yaitu mengirim santri-santri yang loyalitasnya tinggi kepada lembaga masyarakat, untuk memberikan ilmu agama dan memperdalam ilmu dilembaga-lembaga pendidikan sekitar pondok pesantren. c) Memberikan motivasi serta evaluasi kepada santri terhadap pengajaran dan pembelajaran dalam kegiatan dakwah santri di pondok pesantren. d) Menggalakakan terus majelismajelis ta'lim, ditiap-tiap rumah, masjid-masjid maupun kampung-kampung, dengan mengirim da'i yang telah layak uji ke kampung halamanya. e) Meningkatkan professionalisme para guru pada bidangnya dengan terus mengikutikursus-kursus,pelatihan-pelatihan, training-training atau melanjutkan jenjang studi ke tingkat yang tinggi. f)Menjalin silaturrohim antar organisasi atau lembaga urusan umat untuk menyamakan visi dan missi kebersamaan dalam amar ma'ruf nahi munkar, dalam sebuah agenda berupa pengajian, tabligh akbar atau acara PHBI (Perayaan Hari Besar Islam).Mengirimkan para da'i untuk membina kampung pedalaman dalam bentuk kegiatan perkumpulan pengajian dan kegiatan sosial. Dengan kata lain seorang leader atau pemimpin belum tentu seorang manajer, tetapi seorang manajer bisa berprilaku sebagai seorang pemimpin (Permadi, 2010:11-13).

\section{Peran Pimpinan Dalam Mengawasi Program Kegiatan Untuk Meningkatkan Kualitas Dakwah Santri di Pondok Pesanrren Cipari}

Tujuan pendidikan merupakan bagian terpadu dari faktor-faktor pendidikan. Tujuan termasuk kunci keberhasilan pendidikan (Mujamil Qomar:3).Pada dasarnya, tujuan didirikannya pondok pesantren di bagi manjadi dua, yaitu; tujuan umum, membimbing para santri untuk menjadi manusia yang kepribadian Islam yang sanggup dengan ilmu agamanya menjadi mubaligh di tengah masyarakat. 
Tujuan khusus, mempersiapkan para santri untuk menjadi orang ahli agama, serta mengamalkannya dalam kehidupan bermasyarakat (Noor, 2006:20).

Semua ilmuan manajemen sepakat bahwa pengawasan mempunyai kaitan langsung dengan seluruh proses administrasi dan manajemen, pengawasan berkaitan dengan tujuan yang ingin dicapai, dilaksanakan berdasarkan strategi dasar organisasi yang telah dirumuskan dan ditetapkan. Serta dirinci menjadi program dan rencana kerja. Artinya, seorang manajer tidak akan mengamati penyelenggaraan kegiatan-kegiatan operasional dan mengukur hasil yang dicapai oleh para bawahannya tanpa adanya rencana (Siagian 2007:125-126).

Pengawasan merupakan proses pengamatan dari seluruh kegiatan organisasi guna lebih menjamin bahwa semua pekerjaan yang sedang dilakukan sesuai dengan rencana yang telah ditentukan sebelumnya.

Pengawasan akan berjalan dengan lancar apabila proses dasar pengawasan diketahui dan ditaati, yang dimaksud dengan proses dasar itu adalah: 1) Penentuan standar hasil kerja, 2) Pimpinan Pondok Pesantren, 3)Pengukuran hasil pekerjaan, 4) Koreksi terhadap penyimpangan yang mungkin terjadi (Siagian, 2007:128).

Dalam pengawasan ada juga bimbingan maka dari itu hal ini memiliki peran yang cukup penting maka dari itu,

Ketika menjadi seorang pembimbing, seseorang paling tidak perlu memiliki beberapa keterampilan yang menunjang seseorang menjadi kompeten dalam membimbing. Mulai dari Keterampilan membentuk-pesan menambah keakuratan dan kejelasan pesan yang dikirim. Kemudian Keterampilan suasana-percakapan menambah kemungkinan seseorang dan partnernya mengembangkan hubungan yang saling mendukung, yaitu hubungan yang menimbulkan kepercayaan satu sama lain. Selanjutnya, keterampilan mendengarkan untuk memahami menambah kemungkinan seseorang bisa memahami makna orang lain. Tak kalah penting, keterampilan empati-respon menambah kemungkinan seseorang mampu memahami dan merespon pengalaman emosional orang lain. Serta, Keterampilan menyingkap menambah kemungkinan seseorang akan berbagi gagasan dan perasaan dengan cara yang jujur dan sensitif. Persiapan yang mantap sebelum pelaksanaan latihan akan membantu dan menjamin lancarnya pelaksanaan latihan, serta tercapainya sesuai dengan yang diharapkan.

Walaupun demikian, selama proses latihan masih sering muncul perkembangan dan masalah yang tidak terbayangkan sebelumnya. Masalah itu adakalanya berkaitan dengan materi, judul, pelatih, ataupun peserta. Oleh karenanya selama pelaksanaan pelatihan diperlukan kesiapan dan kesediaaan pihak penyelenggara untuk mengadakan penyesuaian bila memang perlu. Agar dapat diadakan penyesuaian yang tepat dan dilakukan pada waktu yang tepat juga. Untuk 
Peran Pimpinan Pondok Pesantren dalam Meningkatkan Kualitas Dakwah Santri itu hendaknya ada upaya penyesuaian yang dapat dilakukan.

Paling tidak ada empat fungsi dasar fungsi fasilitatif dari seorang fasilitator, yaitu: Pertama, Stimuli emosional, menggambarkan prilaku fasilitator yang bergairah, ekspresif yang berpribadi dan penuh emosi. Fungsi ini dilaksanakan di tengah para peserta. Kedua, Kepedulian, adalah isu yang terpisah dari keahlian teknis. ia dibuktikan dengan pengembangan khusus, yang hangat dengan anggota kelompok. Ketiga, Atribut yang bermanfaat. Ia dicapai dengan pesiapan penjelasan perilaku perubahan kognitif dan definisi kerangka kerja untuk berubah. Hal ini memberikan manfaat untuk pengalaman. Keempat, Fungsi ekskutif, yaitu pendekatan."

Pengawasan adalah tindakan mengkaji apakah kegiatan-kegiatan yang dilakukan para anggota kelompok sesuai dengan rencana yang telah ditetapkan. Namun, kata "Pengawasan" sering mempunyai konotasi yang tidak menyenangkan karena dianggap akan mengancam kebebasan otonomi pribadi. Padahal organisasi sangat memerlukan pengawasan untuk menjamin tercapainya tujuan (Handoko, 2004:367). Pengawasan ini perlu dilaksanakan untuk memperoleh kepastian bahwa pekerjaan yang dilakukan oleh para anggota kelompok selaras dengan tujuan yang telah ditetapkan. Pengawasan dalam manajemen bukan saja untuk menapai tujuan organisasi tetapi juga untuk menciptakan keyakinan yang kental dari masyarakat terhadap pengelolaan Pondok Pesantren. Sehingga masyarakat lebih yakin dan memberikan kepercayaannya kepada Pondok Pesantren. Terlaksananya fungsi ini akan membuat semua pengurus tahu akan adanya kesalahan kekurangan, rintangan, tantangan dan kegagalan dalam mencapai tujuan Pondok Pesantren. Berdasarkan hasil wawancara dengan Ust. Suherlan bahwa

"Pengawasan yang biasa dilakukan di Pondok Pesantren Cipari dengan mengambil jalannya pelaksanaan kegiatan, mengukur keberhasilan dan kegagalannya dengan standar sebagaimana yang telah di tetapkan dalam perencanaan, khusunya dalam kegiatan-kegiatan dalam rangka meningkatkan kualitas dakwah santri. Untuk selanjutnya memperbaiki kesalahan dan kekurangan serta mencegah terjadinya kegagalan." (Wawancara, 6 Januari 2018 ).

Fungsi pengawasan ini dilaksanakan oleh pimpinan pondok pesantren ketika telah melaksanakan kegiatan, maka pimpinan dan seluruh staf selalu mengadakan evaluasi terhadap jalannya kegiatan yang telah dilakukan, apakah lebih baik dari sebelumnya atau malah sebaliknya, biasanya dalam bentuk rapat terbatas. Yaitu dengan memberikan laporan kepada setiap pengurus yang telah mendapatkan tugas. Hal ini dilakukan tidak hanya setiap telah melakukan kegiatan melainkan dilaksanakan pada setiap program.

Pondok Pesantren Cipari melakukan pengawasan dan penilaian. 
Dimaksudkan agar pemimpin dapat mengambil tindakan pencegahan tindakan terhadap kemungkinan terjadinya penyimpangan dan kekurangan yang ada. Sehingga akan dapat mengurangi kesalahan yang sedang berlangsung. Disamping itu dapat dapat melakukan usaha-usaha peningkatan penyempurnnaan sehingga proses pelaksanaan kegiatan khususnya dalam meningkatkan kualitas dakwah santri tidak berhenti. Melainkan semakin meningkat dan sempurna.

Pondok Pesantren Cipari diharapkan lebih proaktif dalam melaksanakan dan merumuskan kegiatan dakwah santri, dikarenakan pada saat ini dakwah bukan hanya bisa dilakukan secara langsung tapi dakwah pun bisa dilakukan melalui internet. Hal tersebut merupakan sebuah tantangan zaman di masa sekarang. Diadakannya kegiatan tambahan untuk menunjang aktifitas dakwah santri, seperti pembuatan majalah santri, jurnal santri dan lain-lain.

Adanya penguatan sinergitas yang dibangun antara pondok pesantren dengan pihak yang terlibat dalam mengarahkan program-program, seperti membangun jaringan ke pemerintah kabupaten khususnya pemerintah desa setempat, yang diharapkan akan lebih mendorong perkembangan pondok pesantren, agar ikut andil dan bahu-membahu dalam membantu dan menjalankan Dakwah Islamiyyah.

Evaluasi-evaluasi program maupun kegiatan dilakukan dengan lebih bersifat kekeluargaan serta lebih memfokuskan pada tema dakwah yang lebih difokuskan pada pengetahuan moderen yang menarik untuk semua kalangan khususnya untuk masa sekarang.

Namun demikian, kedudukan kyai dalam pesantren bukanlah sebagai penguasa, melainkan pembimbing bagi para santrinya dalam berbagai hal. Fungsi ini menghasilkan peran Kyai sebagai peniliti, penyaring dan akhimya asimilator aspek-aspek kebudayaan dari luar yang masuk ke pesantren. Karena para santri nanti mengembangkan aspek-aspek kebudayaan yang telah memperoleh imprimatur sang Kiyai, di masyarakat mereka sendiri, dengan sendirinya peran kyai sebagai agen budaya juga tidak dapat dianggap kecil, sebagaimana disinyalir oleh para sarjana yang melakukan penelitian "proyek modjokuto" dua puluh tahunan yang lalu (Wahid, 1983:47).

\section{PENUTUP}

Berdasarkan data yang diperoleh dari hasil analisis, maka dapat ditarik kesimpulan bahwa: 1) Peran pimpinan Pondok Pesantren Cipari dalam mengarahkan proses pendidikan guna meningkatkan kualitas dakwah santri terus dikembangkan, hal tersebut terlihat dari terus berjalannya kegiatan-kegiatan para santri untuk menunjang kemampuan dalam berdakwah dan hal tersebut tercermin dalam salah-satu kegiatan pondok pesantren yaitu muhadharah yang rutin dijalankan setiap minggunya, 2) Peran pimpinan Pondok Pesantren Cipari dalam mengarahkan program terlihat pada proses pengorganisasian yang menghasilkan 
Peran Pimpinan Pondok Pesantren dalam Meningkatkan Kualitas Dakwah Santri sebuah rumusan struktur organisasi dan pendelegasian wewenang dan tanggung jawab, pola yang dibangun sangat khas, musyawarah untuk mufakat selain pemimpin pun menjalankan fungsinya sebagai penentu kebijakan. Jadi, yang ditonjolkan adalah wewenang yang mengikuti tanggung jawab, bukan tanggung jawab yang mengikuti wewenang. Seperti halnya Islam sendiri sangat perhatian dalam memandang tanggung jawab dan wewenang sebagaimana yang telah dicontohkan oleh Rasulullah SAW. yang mengajak para sahabat untuk berpartisipasi melalui pendekatan empati yang sangat persuasive melalui musyawarah. 3) Pimpinan Pondok Pesantren Cipari mempunyai proses pengawasan yang biasa dilakukan di Pondok Pesantren Cipari dengan mengambil jalannya pelaksanaan kegiatan, mengukur keberhasilan dan kegagalannya dengan standar sebagaimana yang telah di tetapkan dalam perencanaan, khusunya dalam kegiatan-kegiatan dalam rangka meningkatkan kualitas dakwah santri. Untuk selanjutnya memperbaiki kesalahan dan kekurangan serta mencegah terjadinya kegagalan. Selain itu pondok pesantren pun mempunyai cara sendiri dalam melakukan evaluasi dalam kegiatan, hal tersebut terlihat dalam satu kegiatan yang rutin dijalankan dalam upaya melahirkan kader-kader dakwah yang baik, yaitu muhadharah. Evaluasi dilakukan oleh pembimbing kelompok masing-masing dan bagian pendidikan santri tentunya dalam pengawasan pimpinan pondok pesantren. Bentuk evaluasi yang dilakukan oleh pembimbing pada kelompok yang dibimbingnya adalah; Memberikan penilaian kepada pera peserta yang tampil; Mendiskusikan pada masing-masing kelompok untuk kegiatan berikutnya. Sedangkan evaluasi pada kegiatan muhadharah pada seluruh kelompok yang dilakukan oleh bagian pendidikan adalah; Memberikan penilaian pada kelompok terbaik dan mengumumkannya pada akhir semester; Mengadakan diskusi setiap bulan dengan kelompok muhadharah.

\section{DAFTAR PUSTAKA}

A'la, A. (2006).Pembaharuan Pesantren, Pustaka Pesantren, Yogyakarta.

Arifin Abdullrachman (2004) Teori pengembangan Clan Filosofi Kepemimpinan

Kerja, Ikhtiar Baru, Jakarta

Handoko, T H. (2004). Manajemen Personalia dan Sumberdaya Manusia. BPFE, Yogyakarta.

PermadiK. (2010)Pemimpin dan Kepemimpinan dalam Manajemen, Rineka Cipta, Jakarta.

Kusnawan, A. (2015) Konsep Manajemen Pelatihan Dakwah.Ilmu Dakwah: Academic Journal for Homiletic Studies, [S.1.], v 4,n. 12,p.335-370.

MunirM. \&Waliyu Ilaihi (2006)Manajemen Dakwah. Kencana, Jakarta.

Wahid, A. (2001). Pesantren dan Pembaharuan, LP3ES, Jakarta. 
M.S. Ghazi Alkhairy 